\title{
Mitigating Aflatoxin Contamination in Groundnut through A Combination of Genetic Resistance and Post-Harvest Management Practices
}

\author{
Manish K. Pandey ${ }^{1, *}$, Rakesh Kumar ${ }^{1}\left(\right.$, , Arun K. Pandey ${ }^{1}$, Pooja Soni ${ }^{1}$, Sunil S. Gangurde ${ }^{1}$ (D), \\ Hari K. Sudini ${ }^{1}$, Jake C. Fountain ${ }^{2,3}$, Boshou Liao ${ }^{4}$, Haile Desmae ${ }^{5}$, Patrick Okori ${ }^{6}$, \\ Xiaoping Chen ${ }^{7}$, Huifang Jiang ${ }^{4}$, Venugopal Mendu ${ }^{8}\left(\mathbb{D}\right.$, , Hamidou Falalou ${ }^{9}$, Samuel Njoroge ${ }^{6}$, \\ James Mwololo ${ }^{6}$, Baozhu Guo ${ }^{2}$, Weijian Zhuang ${ }^{10}$, Xingjun Wang ${ }^{11}$, Xuanqiang Liang ${ }^{7}$ and \\ Rajeev K. Varshney ${ }^{1}$ \\ 1 International Crops Research Institute for the Semi-Arid Tropics (ICRISAT), Hyderabad 502324, India; \\ k.rakesh@cgiar.org (R.K.); p.arunkumar@cgiar.org (A.K.P.); P.Soni@cgiar.org (P.S.); g.sunil@cgiar.org (S.S.G.); \\ h.sudini@cgiar.org (H.K.S.); r.k.varshney@cgiar.org (R.K.V.) \\ 2 Crop Protection and Management Research Unit, United State Department of Agriculture-Agricultural \\ Research Service (USDA-ARS), Tifton, GA 31793, USA; jfount1@uga.edu (J.C.F.); \\ baozhu.guo@ars.usda.gov (B.G.) \\ 3 Department of Plant Pathology, University of Georgia, Tifton, GA 31793, USA \\ 4 Oil Crops Research Institute (OCRI) of Chinese Academy of Agricultural Sciences (CAAS), \\ Wuhan 430062, China; liaoboshou@caas.cn (B.L.); peanutlab@oilcrops.cn (H.J.) \\ 5 International Crops Research Institute for the Semi-Arid Tropics (ICRISAT), Bamako BP 320, Mali; \\ h.desmae@cgiar.org \\ 6 International Crops Research Institute for the Semi-Arid Tropics (ICRISAT), Lilongwe PB 1096, Malawi; \\ P.Okori@cgiar.org (P.O.); S.Njoroge@cgiar.org (S.N.); J.Mwololo@cgiar.org (J.M.) \\ 7 Crops Research Institute (CRI) of Guangdong Academy of Agricultural Sciences (GAAS), \\ Guangzhou 510640, China; chenxiaoping@gdaas.cn (X.C.); liangxuanqiang@gdaas.cn (X.L.) \\ 8 Department of Plant and Soil Science, Texas Tech University, Lubbock, TX 79409, USA; \\ venugopal.mendu@ttu.edu \\ 9 International Crops Research Institute for the Semi-Arid Tropics (ICRISAT), Niamey BP 12404, Niger; \\ H.Falalou@cgiar.org \\ 10 Institute of Oil Crops, Fujian Agriculture and Forestry University, Fuzhou 350002, China; weijianz1@163.com \\ 11 Shandong Academy of Agricultural Sciences, Jinan 250108, China; xingjunw@hotmail.com \\ * Correspondence: m.pandey@cgiar.org
}

Received: 16 April 2019; Accepted: 23 May 2019; Published: 3 June 2019

\begin{abstract}
Aflatoxin is considered a "hidden poison" due to its slow and adverse effect on various biological pathways in humans, particularly among children, in whom it leads to delayed development, stunted growth, liver damage, and liver cancer. Unfortunately, the unpredictable behavior of the fungus as well as climatic conditions pose serious challenges in precise phenotyping, genetic prediction and genetic improvement, leaving the complete onus of preventing aflatoxin contamination in crops on post-harvest management. Equipping popular crop varieties with genetic resistance to aflatoxin is key to effective lowering of infection in farmer's fields. A combination of genetic resistance for in vitro seed colonization (IVSC), pre-harvest aflatoxin contamination (PAC) and aflatoxin production together with pre- and post-harvest management may provide a sustainable solution to aflatoxin contamination. In this context, modern "omics" approaches, including next-generation genomics technologies, can provide improved and decisive information and genetic solutions. Preventing contamination will not only drastically boost the consumption and trade of the crops and products across nations/regions, but more importantly, stave off deleterious health problems among consumers across the globe.
\end{abstract}


Keywords: Aspergillus flavus; aflatoxin contamination; groundnut; genetic resistance; post-harvest management

Key Contribution: This article provides an overview on the complex molecular regulatory events associated with the aflatoxin resistance mechanisms in groundnut. Emphasis is placed for more research on discovery of resistant lines, markers, genes and pathways which together with pre- and post-harvest management practices can mitigate aflatoxin contamination in groundnuts.

\section{Introduction}

Aflatoxin contamination is a food safety concern that has adverse financial implications and health consequences in groundnut growing regions across the globe. Aflatoxins are a group of mycotoxins and highly toxic secondary metabolites produced by four Aspergillus species such as Aspergillus flavus, Aspergillus parasiticus, Aspergillus nomius and Aspergillus tamarii [1-3]. Groundnut, cotton, sunflower, wheat, corn and rice are key hosts for fungus causing aflatoxin outbreaks in the food chain [4]. Aflatoxins contain alternating groups of carbonyl and methylene called polyketides that are carcinogenic, immunosuppressive, hepatotoxic and teratogenic to humans and animals $[5,6]$. Among four prevalent groundnut aflatoxins, B1 and B2 are produced by A. flavus while G1 and G2 are produced by $A$. parasiticus. In addition to health issues, aflatoxin levels beyond a threshold hamper the export quality of groundnuts 20 parts per billion (ppb) in the USA and 4 ppb in Europe [7] resulting in significant economic loss to farmers and traders. Since aflatoxin decomposes at $237-306{ }^{\circ} \mathrm{C}$, cooking, drying, pasteurization and sterilization cannot reduce aflatoxin levels in food [8]. Although calcium chloride, alkaline cooking and steeping, hydroxides and bicarbonates can reduce $84 \%-95 \%$ aflatoxin content [9-11], these treatments also reduce the nutritional quality of the product. If pre-harvest infection in crops can be avoided through host resistance, then managing post-harvest contamination becomes possible using different technologies and practices.

Inconsistent phenotyping results from aflatoxin contamination experiments suggest a large variation in germplasm due to genotype-by-environment $(\mathrm{G} \times \mathrm{E})$, but studies have not led to the identification of stable resistance sources among diverse germplasm. Studies have reported the existence of three types of host-pathogen resistance mechanisms, namely in vitro seed colonization (IVSC), pre-harvest aflatoxin contamination (PAC) and aflatoxin production (AP) detected in different genetic backgrounds [12-16]. However, there are currently no reports on the presence of all three resistance mechanisms in a single genetic background. This provides an opportunity to combine the three resistance mechanisms to achieve stable genetic resistance against Aspergillus infection in the field. Speedy advancements in low-cost sequencing technologies and big data analysis provide opportunities to dissect this tricky trait by deploying complex multi-parent genetic populations (such as MAGIC-multi-parent advanced generation intercross, and NAM-nested association mapping) [17-19]. Further, reliable ELISA-based phenotyping of the three mechanisms on large-scale segregating breeding lines may facilitate the identification of promising lines with resistance to all the mechanisms.

Over the last decade, next-generation sequencing (NGS) technologies accelerated the development of different genomic resources in a given crop that are very affordable even for large genome-polyploid crops such as groundnut $[18,19]$. As a result, high quality reference genomes have been successfully developed for diploid progenitors Arachis duranensis [20,21] and A. ipaensis [21,22] wild tetraploid A. monticola [23] and also for both the subspecies namely, A. hypogaea spp. hypogaea [24] and A. hypogaea spp. fastigiata $[25,26]$ of cultivated groundnut. In addition, comprehensive gene expression atlases are also available [27,28], large-scale genome-wide genetic markers and high density 58K SNPs 'Axiom_Arachis' Array [29] for use in different structural and functional genomics studies. In addition, genetic and transcriptome studies on different mechanisms provide a better understanding 
of biochemical pathways involved in aflatoxin biosynthesis [30-32]. Transgenic technology was deployed to achieve $\sim 90 \%$ reduction in aflatoxin content in groundnut by silencing the aflatoxin producing genes (aflR, aflS, aflep and aflC) using RNAi approach [33]. Transgenic events with reduced levels of aflatoxin were recently developed in groundnut by silencing the aflM and aflP genes through host-induced gene silencing (HIGS) and overexpressing of antifungal plant defensins MsDef1 and MtDef4.2 [34].

Since none of the above-mentioned efforts have provided heritable resistance in the genetic background of popular cultivars, serious efforts are warranted in achieving stable genetic resistance. However, it must be mentioned that post-harvest management practices have been very instrumental in mitigating contamination in the entire food chain. This paper discusses the importance and strategy of combining different resistance mechanisms together with well-tested pre- and post-harvest management and safety practices to deliver aflatoxin-free groundnuts to the food chain (Figure 1). It also advocates the deployment of modern scientific tools and technologies to minimize contamination throughout the value chain, thereby ensuring food safety and consumers' health globally.
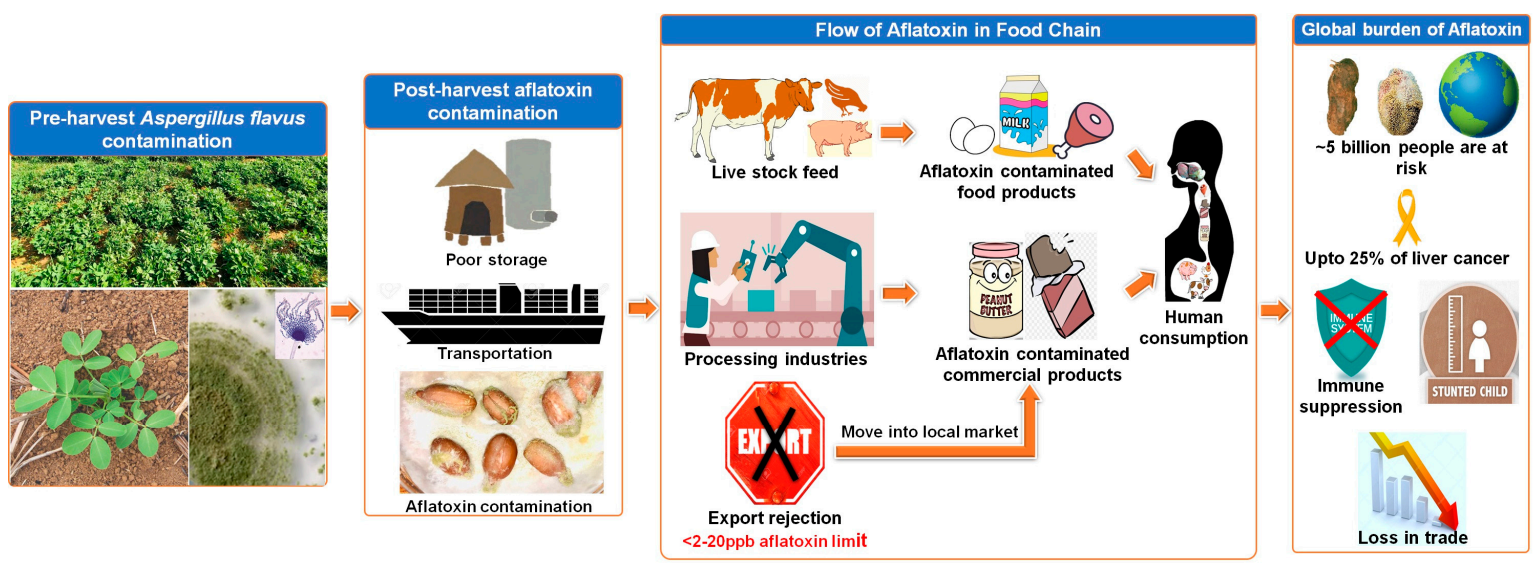

Figure 1. Impact of aflatoxin contamination across the groundnut value chain. Poor storage and inappropriate transportation procedures are the bottlenecks in the post-harvest stage of harvest aflatoxin contamination, subsequently causing financial loss to farmers and traders. Once these contaminated products enter the food-feed chain and travel across it, they can have an adverse impact on human health.

\section{Characterization of Aflatoxin Producing Pathogens}

Polyketide derived aflatoxins are produced by $A$. flavus which is a soil saprophytic fungus and opportunistic pathogen that impacts human and animal health. A. flavus grow well at $28-30{ }^{\circ} \mathrm{C}$ and $25-35{ }^{\circ} \mathrm{C}$ and is readily able to colonize in most environments whenever there is a suitable nutrient rich source of carbon and nitrogen [35] A. flavus mode of replication is majorly by asexual reproduction, but it also forms sclerotia or conidia in soil and in plant tissue as hardened masses of desiccated and melanized mycelia that are able to survive adverse nutritional conditions [36]. However, an earlier study reported that sexual reproduction also takes place among compatible groups of A. flavus strains [37]. Furthermore, colonies which are produced by A. flavus are powdery masses of yellow-green spores and reddish gold on the upper and lower surface area. Most of the plants which were invaded and/or colonized by A. flavus do not show any visible symptoms on the foliage except aflatoxin accumulation in the grains/seeds.

Groundnut pods develop beneath the soil, which is the main source of inoculum for A. flavus leading to infection in groundnut seeds [38,39]. The toxigenic pathogens produce a high level of toxins in the infected seeds with high protein and lipid content [40]. Based on phenotyping, toxigenic strains can be categorized into $S$ and $L$ type. $S$ strains produce high levels of aflatoxins and numerous sclerotia (average diameter $<400 \mu \mathrm{m}$ ) whereas $\mathrm{L}$ strains produce large sclerotia but fewer aflatoxins [41] Aflatoxins (AFs) are secondary metabolites produced by the fungal plant parasite pathogens i.e., 
A. flavus and A. parasiticus [42]. Aflatoxins belong to a family of compounds called difuranocoumarins and are grouped under $\mathrm{AFB}_{1}, \mathrm{AFB}_{2}, \mathrm{AFG}_{1}$ and $\mathrm{AFG}_{2}$ based on fluorescence emission and their relative mobility on silica gel. Of these, $\mathrm{AFB}_{1}$ is most toxic and is produced by both $A$. flavus and A. parasiticus. $\mathrm{AFG}_{1}$ and $\mathrm{AFG}_{2}$ are produced exclusively by $A$. parasiticus. Infections from $A$. flavus are more prevalent in Asia and Africa while A. parasiticus is prevalent in Americas. Groundnuts tend to be colonized and contaminated by Aspergillus sp. at different stages and aflatoxin production occurs at pre-harvest, during harvest, post-harvest drying, in storage and also during transportation along the value chain $[43,44]$.

Aflatoxin contamination in groundnuts is aggravated by heat and drought stresses $[45,46]$. Under drought conditions, aflatoxin contamination increases due to reduced moisture in the pod, resulting in cracks in the pod wall that allows the penetration of A. flavus [47]. Damaged pods have more aflatoxin compared to undamaged shells [48]. Under drought conditions, the production of phytoalexin is inhibited by decreasing kernel water activity, which increases aflatoxin contamination [49]. Thus, drought predisposes groundnut to aflatoxin production [50]. Although drought intensity increases aflatoxin contamination, drought tolerance does not lead to less aflatoxin contamination [51]. It has been reported that expression of AFs biosynthetic gene cluster [52] and aflatoxin production have been regulated through various environmental and nutritional factors including carbon sources [53] and oxygen availability [54-57].

The aflatoxin biosynthetic pathway has been well characterized in A. parasiticus and A. flavus [58]. Extensive research has identified a $70 \mathrm{~kb}$ DNA cluster consisting of two specific transcriptional regulators (aflR and aflS) and 25 co-regulated downstream metabolic genes in the aflatoxin biosynthetic pathway [59-62]. On average, about $2.8 \mathrm{~Kb}$ of the genomic DNA region contains one gene. The genomic region has three large gene fragments of about $5-7 \mathrm{~Kb}$ each for the fatty acid synthase $\alpha(F A S \alpha), F A S \beta$ and the polyketide synthase (PKS). The average size of the other 22 genes is about $2 \mathrm{~Kb}$ towards $5^{\prime}$ end with no ORF. The expression of the two transcriptional regulators (aflR and aflS) are controlled by many regulators, i.e., CreA transcription factor, VelB/VeA/LaeA complex, and a cell surface-localized G-protein coupled receptor complex [52,63]. Most early studies focused on controlling AFB 1 production in crops with a few dwelling on factors responsible for aflatoxin contamination.

\section{Adverse Impacts of Aflatoxin Contamination on Human Health and the Economy}

Aflatoxin adversely affects $>5$ billion people who are chronically exposed to a large amount $(>1000 \mathrm{ppb})$ of toxin [64]. The exposure to high aflatoxin influences various biological pathways in humans through the interaction of epoxide with proteins and DNA. Exposure to the toxic effects of aflatoxin negatively affects nutrition of poor people as well as the economy, accounting for $40 \%$ of prevalent diseases affecting health [65]. Aflatoxin also has implications on the economic, social and political aspects of society. Aflatoxin is predominantly perceived as leading to aflatoxicosis and exists in two forms of acute intoxication leading to liver damage and chronic subsymptomatic exposure [65]. At present, the global burden of aflatoxin-driven hepatocellular carcinoma (HCC) or liver cancer is around $25 \%$, mostly prevalent in developing countries due to poor post-harvest management and regular consumption of food contaminated with aflatoxin [66,67]. In the 1960s, the death of 2219 chicks in poultry farms in Mysore in Karnataka state of India, led to the origin of the word 'aflatoxicosis' [68]. Deaths in poultry due to aflatoxin were also reported in 1961 in turkeys fed imported (and contaminated) groundnut meal (Turkey " $X$ " disease) $[69,70]$. A deleterious mutation in the P53 tumor-suppressor gene and activation of dominant oncogenes leads to hepatomas ( $64 \%$ of cancers) which are a predominant cancer [71,72]. Due to these implications on health, aflatoxin was placed on the list of Rapid Alert System for Food and Feed (RASFF) of the European Union in 2008. Aflatoxin $\left(\mathrm{AFB}_{1}\right)$ has also been categorized as a class 1 carcinogen by the International Agency for Research on Cancer (IARC). This has resulted in the regulation of toxins to very low concentrations, i.e., $20 \mathrm{ppb}$ in grains and $0.5 \mathrm{ppb}$ in milk in the United States and $4 \mathrm{ppb}$ in food for direct consumption (including groundnut) in some European countries [7]. 
In addition to groundnuts, aflatoxin also contaminates linseeds, sunflower seeds, cereals, beans and poultry due to contaminated feed [73]. Reports suggest that aflatoxin contamination in agricultural crops may lead to an annual loss of more than US\$ 750 million in Africa [74]. In the USA, aflatoxin contamination leads to an annual income loss of more than US $\$ 100$ million [75]. High levels were detected in children in South Africa, Durban, Nigeria and Sudan [76-78]. It also leads to the rejection of valuable products in the international market [79]. Products that do not meet the aflatoxin standards are rejected at the channel of distribution or sold cheaply and enter the local market [80]. In Eastern Cape area of South Africa, the most predominant aflatoxin B1 toxin was found at a concentration of 27,163 and 16,505 ppb in groundnut butter provided to children. However, $10 \mathrm{ppb}$ is the maximum concentration, of which $5 \mathrm{ppb}$ was that of B1 aflatoxin (http://scienceinafrica.com/health/aflatoxin-peanut-butter-mrc-policy-brief).

Levels of aflatoxin contamination depend on the Aspergillus species, growing and storage conditions and differ from country to country [81,82]. Factors such as genotype, soil texture, moisture deficit and insect infestation also have a bearing on severity of contamination [82]. Data on annual consumption from different countries show that exposure to aflatoxin was $11.7-2027 \mathrm{ng} / \mathrm{kg} / \mathrm{day}$ in southern Guangxi province of China, 3.5-14.8 ng/kg/day in Kenya, 38.6-183.7 ng/kg/day in Mozambique, 11.4-158.6 $\mathrm{ng} / \mathrm{kg} / \mathrm{day}$ in Swaziland and $16.5 \mathrm{ng} / \mathrm{kg} /$ day in Transkei. In Thailand, it was $6.5-53 \mathrm{ng} / \mathrm{kg} /$ day whereas in the United States it was estimated to be $6.5-53 \mathrm{ng} / \mathrm{kg} /$ day [83]. A study in Ghana revealed estimated aflatoxin exposure in groundnut to be $9.9-99.2 \mathrm{ng} / \mathrm{kg} /$ day [84].

Standard food safety parameters set by national regulatory bodies in different countries for the benefit of human health and permissible limits differ among countries [85]. This may lead to trade loss due to high cost of meeting the standards and cost of testing, and eventual loss of admissibility into foreign markets [86]. According to food safety and standard regulations the permissible limit for aflatoxin in food commodities for sale in the Indian market is $30 \mu \mathrm{g} / \mathrm{kg}$ or ppb, while the tolerance value for aflatoxin M in milk is $0.5 \mu \mathrm{g} / \mathrm{kg}$. However, the European Union (EU) has stringent limits for aflatoxin in dried nuts, cereals and spices, ranging from 2-12 $\mu \mathrm{g} / \mathrm{kg}$ for B1 aflatoxin to $4-15 \mu \mathrm{g} / \mathrm{kg}$ for total aflatoxins, whereas, for infant foods, the range varies from 0.10 to $0.25 \mu \mathrm{g} / \mathrm{kg}$ [87].

\section{Current Understanding of Resistance to Aflatoxin Contamination Based on Genetic, Genomic, Transcriptomic and Proteomic Studies}

Deciphering genotype to phenotype association requires an understanding of gene networks and pathways of biological systems to target complex traits such as aflatoxin contamination in groundnut. Multiple efforts have been made for phenotyping diverse groundnut genotypes leading to identification of several promising lines showing resistance/moderate resistance for $A$. flavus infection and aflatoxin production (Table 1). Modern approaches such as molecular genetics, genomics, transcriptomics and proteomics studies in groundnut have become increasingly more effective (Figure 2). A very recent study on identification of linked markers for aflatoxin resistance reported quantitative trait loci (QTLs) in a recombinant inbred line (RIL) population (Zhonghua $10 \times$ ICG 12625) [88]. The phenotyping of this population was performed for percent seed infection index (PSII), and aflatoxin B1 (AFB 1 ) and aflatoxin $\mathrm{B} 2\left(\mathrm{AFB}_{2}\right)$ content. Two QTLs for PSII and 12 QTLs for aflatoxin accumulation were detected by unconditional analysis. Interestingly, four QTLs ( $q A F B 1 A 07$ and $q A F B 1 B 06.1$ for $\mathrm{AFB}_{1}$ and $q A F B 2 A 07$ and $q A F B 2 B 06$ for $\left.\mathrm{AFB}_{2}\right)$ showed major and stable effects $(9.32 \%-21.02 \%$ PVE) [88]. It was important to note the discovery of two co-localized genomic regions on A07 (not only qAFB1A07 and qAFB2A07) and on A06 (qAFB1B06.1 and qAFB2B06). A closer look at the genotyping and phenotyping data suggested additive effects between two QTLs ( $q A F B 1 A 07$ and $q A F B 1 B 06.1$ ) leading to low $\mathrm{AFB}_{1}$ and $\mathrm{AFB}_{2}$ accumulation [88]. These are encouraging results in addition to several comprehensive trait mapping studies underway using association mapping panel and bi-parental and multi-parental genetic populations and transcriptomics at leading research organizations such as ICRISAT-India, University of Georgia-USA, USDA-USA, and Oil Crops Research Institute of the CAAS-China. 
Table 1. A summary of the screening and characterization of groundnut germplasm using different phenotyping methods leading to identification of aflatoxin-resistant genotypes.

\begin{tabular}{|c|c|c|c|c|c|c|}
\hline $\begin{array}{l}\text { Resistance } \\
\text { Mechanism }\end{array}$ & Sample Size and Material Type & Toxigenic Species & Screening Method & Significant Outcome & $\begin{array}{l}\text { Resistant Varieties } \\
\text { Identified }\end{array}$ & Reference \\
\hline \multirow[t]{2}{*}{ 1. PHAC } & 13 elite varieties and landraces & A. flavus & $\begin{array}{l}\text { Mycelial growth on the } \\
\text { surface of kernels }\end{array}$ & $\begin{array}{l}\text { The compact arrangement of } \\
\text { palisade-like layers of the } \\
\text { seed testa is resistant to } \\
\text { PHAC }\end{array}$ & $\begin{array}{l}\text { Igola, Serenut } 1 \text {, Serenut } 2 \\
\text { and entry } 99527\end{array}$ & [14] \\
\hline & 10 elite varieties & A. flavus & $\begin{array}{l}\text { Seed infection coverage } \\
\text { and intensity analyzer } \\
\text { (SICIA) }\end{array}$ & $\begin{array}{l}\text { All groundnut genotypes } \\
\text { support PHAC, but AP } \\
\text { varies among genotypes }\end{array}$ & $\begin{array}{l}\text { ICG 1471, NC3033, ICGV } \\
88145, \text { GT-C20 }\end{array}$ & [15] \\
\hline \multirow{2}{*}{ 2. PAC } & 7 elite varieties & A. flavus & $\begin{array}{l}\text { Green conidial heads of } \\
\text { A. flavus group and black } \\
\text { conidial heads of } A \text {. niger }\end{array}$ & $\begin{array}{l}\text { Low levels of linoleic acid do } \\
\text { not affect aflatoxin } \\
\text { production during PAC }\end{array}$ & F1334 and F1344 & [89] \\
\hline & 11 germplasm lines & A. flavus & $\begin{array}{l}\text { Aflatoxin estimated using } \\
\text { ELISA }\end{array}$ & $\begin{array}{l}\text { PAC increases when exposed } \\
\text { to terminal drought }\end{array}$ & $\begin{array}{l}\text { ICGV 98305, ICGV 98348, } \\
\text { ICGV 98353, Tifton } 8\end{array}$ & [47] \\
\hline \multirow{6}{*}{ 3. IVSC } & 40 elite varieties & A. flavus & $\begin{array}{l}\text { Seeds with } A \text {. flavus } \\
\text { colonies were counted }\end{array}$ & $\begin{array}{l}\text { IVSC increases with } \\
\text { increased drought stress }\end{array}$ & $\begin{array}{l}\text { 55-437, PI 337409, PI } \\
\text { 337394F, 73-30 }\end{array}$ & {$[90]$} \\
\hline & 35 wild accessions & A. flavus & IVSC and AP & $\begin{array}{l}\text { A. pusilla, A. chiquitana, } A \text {. } \\
\text { triseminata species resistant to } \\
\text { IVSC and AP }\end{array}$ & $\begin{array}{l}\text { ICG 13212, ICG 11560, } \\
\text { ICG 8131, ICG } 14875\end{array}$ & [13] \\
\hline & 37 cultivars & A. flavus & A. flavus inoculated & $\begin{array}{l}\text { Different varieties produce } \\
\text { aflatoxin B1 and B2 at } \\
\text { different levels during IVSC }\end{array}$ & PI 337394F, PI 337409, J-11 & [91] \\
\hline & $\begin{array}{l}>100 \text { accessions, breeding lines } \\
\text { and commercial varieties }\end{array}$ & A. flavus & $\begin{array}{l}\text { Visual development of } \\
\text { conidial spores }\end{array}$ & $\begin{array}{l}\text { Lower moisture has higher } \\
\text { level of resistance to } \\
\text { penetration by A. flavus } \\
\text { during IVSC }\end{array}$ & PI 337394, PI 337409 & [92] \\
\hline & 14 varieties & A. parasiticus & $\begin{array}{l}\text { Fungal sporulation } \\
\text { recorded }\end{array}$ & $\begin{array}{l}\text { Higher moisture reduces } \\
\text { infection rate during IVSC }\end{array}$ & J-11, Lampang & [93] \\
\hline & 12 breeding and germplasm lines & A. flavus, A. parasiticus & $\begin{array}{l}\text { Immunoaffinity column } \\
\text { fluorometer method }\end{array}$ & $\begin{array}{l}\text { Highly significant }(E),(G) \\
\text { and }(G \times E) \text { interactions } \\
\text { identified }\end{array}$ & AR-2, GFA-1 & [94] \\
\hline
\end{tabular}


Table 1. Cont

\begin{tabular}{|c|c|c|c|c|c|c|}
\hline $\begin{array}{l}\text { Resistance } \\
\text { Mechanism }\end{array}$ & Sample Size and Material Type & Toxigenic Species & Screening Method & Significant Outcome & $\begin{array}{l}\text { Resistant Varieties } \\
\text { Identified }\end{array}$ & Reference \\
\hline \multirow{4}{*}{ IVSC and AP } & $\begin{array}{l}25 \text { breeding lines and cultivars of } \\
\text { Africa }\end{array}$ & $\begin{array}{l}\text { A. flavus and } A . \\
\text { parasiticus }\end{array}$ & $\begin{array}{l}\text { ELISA for toxin } \\
\text { estimation }\end{array}$ & $\begin{array}{l}\text { VAR } 27 \text { variety produced } \\
\text { least aflatoxin but showed } \\
\text { higher IVSC }\end{array}$ & $\begin{array}{l}\text { ICGV 87084, ICGV 87094, } \\
\text { ICGV } 87110\end{array}$ & [12] \\
\hline & 67 CSL lines and varieties & A. flavus & Seed colonization test & $\begin{array}{l}\text { Varieties with compact and } \\
\text { thicker testa resistant to IVSC }\end{array}$ & $12 \mathrm{CS}-104,73-33$ & [16] \\
\hline & 850 cultivars and elite lines & A. flavus & $\begin{array}{l}\text { Seed colonies and } \\
\text { aflatoxin estimated }\end{array}$ & $\begin{array}{l}\text { Some varieties are susceptible } \\
\text { to IVSC but, resistant to AP }\end{array}$ & $\begin{array}{l}\text { PI } 337394 \mathrm{~F}, \text { PI337409 and } \\
\text { UF71513 }\end{array}$ & [95] \\
\hline & 561 germplasm lines & A. flavus & $\begin{array}{l}\text { Seed infection percentage } \\
\text { and aflatoxin production } \\
\text { recorded }\end{array}$ & $\begin{array}{l}\text { ICRISAT core collection has } \\
\text { more resistance to IVSC than } \\
\text { the China core collection }\end{array}$ & $\begin{array}{l}\text { ICG } 12625 \text { (resistant to } \\
\text { AP) and ICG } 4750 \\
\text { (resistant to seed } \\
\text { invasion) }\end{array}$ & [96] \\
\hline
\end{tabular}

IVSC: In vitro seed colonization; PAC: Pre-harvest aflatoxin contamination; AP: Aflatoxin production; PHAC: Post-harvest aflatoxin contamination; CSL: Chromosome Substitution Lines; E: Environment; G: Genotype; and G × E: Genotype × Environment. 


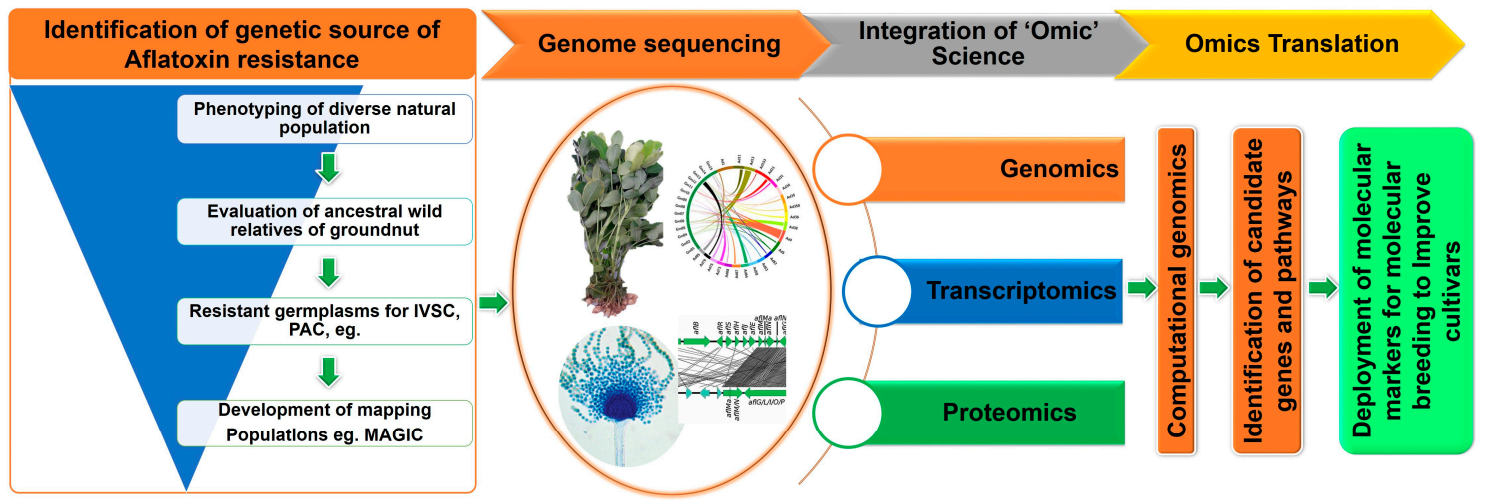

Figure 2. Deployment of a combination of genetic and omics approaches will develop better understanding of the pathways and genomic tools which will help in tackling aflatoxin contamination in crops through genetic improvement using genomics-assisted breeding.

Genome sequencing of hosts and pathogens have provided insights into complex genetic architecture and novel genes. Further, transcriptomic and proteomic studies have supplemented information on gene expression and the pathways enrichment that govern phenotype. Previously, efforts were made in large-scale sequencing of cDNA to discover the gene expression pattern between susceptible and resistant genotypes and identified defense-related genes upon A. flavus seed colonization [97-99]. However, these studies were based on EST or microarray-based approaches which are less sensitive and provide low coverage for differentially expressed genes. Now, new tools such as sequencing-based RNA-seq have greatly accelerated insights into the molecular understanding of toxin production by pathogens and resistance mechanisms in different crops including groundnut [100-102]. This highly sensitive approach allows efficient discovery of differentially expressed genes on a larger scale. For instance, a recent RNA-seq-based approach enabled the detection of around 129,000 unigenes in groundnut seed upon Aspergillus infection [30-32]. Similarly, an RNA-seq-based transcriptomic study discovered 14,592 genes, of which 13,875 were previously annotated and 717 were novel to the Aspergillus spp. [101]. These studies have profound gene annotation [101] and identified key pathways responsible for mycotoxin production by Aspergillus sp. [102].

Proteomic studies have greatly enhanced the understanding of gene regulation and regulatory networks to explain the molecular mechanism involved in host-pathogen interaction and aflatoxin contamination [103-105] (Table 2). The two-dimensional difference gel electrophoresis (2-D DIGE) based proteomic approach identified a number of proteins corresponding to aflatoxin production in groundnut upon infection by toxigenic strains of $A$. flavus [99]. Though the study reported only 400 protein spots, it provided evidence of host-pathogen interaction by capturing proteins involved in DNA and RNA stabilization, biosynthesis of phytoalexins, immune response, detoxification and metabolic regulation [106]. Recently, a study deployed proteomic approach to gain insights into the pathogen regulatory mechanism involved during oxidative stress, similar to drought stress in groundnut. To reproduce oxidative stress, three isolates-AF13, NRRL3357 and K54A—with high, moderate, and no aflatoxin production, were exposed to $\mathrm{H}_{2} \mathrm{O}_{2}$ and their global proteome variations were studied. As a result, 1173 proteins were identified, and among them 220 were differentially expressed, controlling toxigenic abilities of strains AF13, NRRL3357 and K54A. This suggests that the toxin production abilities of toxigenic strains involve a group of genes that together regulate production of lytic enzymes, oxidative stress tolerance, production of secondary metabolites, pathogenicity, mycelial development, carbohydrate metabolism, etc. $[102,106]$. Together, these studies have advanced our current understanding of genetic regulations and the molecular networks involved in host-pathogen interactions to come up with new strategies in alleviating aflatoxin contamination in groundnut and other crops. For instance, this knowledge has helped researchers and breeders develop aflatoxin contamination-free transgenic maize [107] and groundnut [34] through host-induced gene silencing. 
Table 2. A summary of the transcriptome and proteome based discovery of key genes and pathways involved in aflatoxin contamination in groundnut.

\begin{tabular}{|c|c|c|c|}
\hline Resistance Mechanism & Key Genes/TFs and Pathways Identified & Functional Description & References \\
\hline \multirow{6}{*}{ Aflatoxin Production (AP) } & WRKY & Stress regulative transcription factor & \multirow{4}{*}{ [32] } \\
\hline & $\begin{array}{l}\text { Toll/Interleukin1 receptor-nucleotide binding site } \\
\text { leucine-rich repeat (TIR-NBS-LRR) }\end{array}$ & Highly conserved disease resistant genes in plants & \\
\hline & Ethylene responsive factors & Transcriptionally regulates jasmonate signaling pathway & \\
\hline & Heat shock proteins & Regulates heat shock factors which play vital role in plant defense & \\
\hline & $\begin{array}{l}\text { Pathogenesis-related (PR) 1,2,5 } \\
\text { NBS-LRR genes }\end{array}$ & $\begin{array}{l}\text { Defense-related genes } \\
\text { Disease resistance gene }\end{array}$ & [30] \\
\hline & $\begin{array}{l}\text { WRKY } \\
\text { Ethylene responsive factors } \\
\text { Linoleate 9S-lipoxygenase }\end{array}$ & $\begin{array}{l}\text { Stress regulative transcription factor } \\
\text { Plays intermediary role in salicylic acid pathway } \\
\text { Plays role in Jasmonic acid signal transduction pathway }\end{array}$ & $\begin{array}{l}\text { ICRISAT, } \\
\text { Unpublished }\end{array}$ \\
\hline \multirow{4}{*}{$\begin{array}{l}\text { Pre-Harvest Aflatoxin } \\
\text { Contamination (PAC) }\end{array}$} & $\begin{array}{l}\text { ABR1 } \\
\text { Pathogenesis related-2 } \\
\text { BIG } \\
\text { WRINKLED1 }\end{array}$ & $\begin{array}{l}\text { Ethylene responsive transcription factor and repressor of ABA } \\
\text { signaling } \\
\text { Stress and defense responsive gene } \\
\text { Auxin transport gene } \\
\text { Controls fatty acid biosynthesis pathway }\end{array}$ & [108] \\
\hline & $\begin{array}{l}\text { Defensin } \\
\text { TIR } \\
\text { Chalcone isomerase } 3 \\
\text { EM protein }\end{array}$ & $\begin{array}{l}\text { Defense response } \\
\text { Defense response } \\
\text { Flavonoids biosynthesis } \\
\text { Stress response }\end{array}$ & [109] \\
\hline & $\begin{array}{l}\text { Cupin/Oxalate oxidase } \\
\text { Fatty acid desaturase } 1 \\
\text { Lipoxygenase }\end{array}$ & $\begin{array}{l}\text { Seed storage protein } \\
\text { Regulates fatty acid-biosynthesis pathway } \\
\text { Plays role in Jasmonic acid signal transduction pathway }\end{array}$ & [97] \\
\hline & $\begin{array}{l}\text { Iso-Ara h3 } \\
\text { LEA } 4 \\
\text { Cu/Zn superoxide dismutase II } \\
\text { Heat shock protein }\end{array}$ & $\begin{array}{l}\text { Seed Storage protein } \\
\text { Stress related protein } \\
\text { Antioxidant defensive protein } \\
\text { Regulates heat shock factors which play vital role in plant defense }\end{array}$ & [98] \\
\hline $\begin{array}{l}\text { In Vitro Seed Colonization } \\
\text { (IVSC) }\end{array}$ & $\begin{array}{l}\text { Linoleate 9S-lipoxygenase } \\
\text { Resveratrol synthase } \\
\text { Chalcone synthase } \\
\text { Defensins } \\
\text { Chitinases }\end{array}$ & $\begin{array}{l}\text { Plays role in Jasmonic acid signaling transduction } \\
\text { Biosynthesize stilbene type-phytoalexins } \\
\text { Flavonoids biosynthesis } \\
\text { Defense response } \\
\text { Modulates immune response }\end{array}$ & [31] \\
\hline
\end{tabular}


Table 2. Cont.

\begin{tabular}{lll}
\hline Resistance Mechanism & Key Genes/TFs and Pathways Identified & Functional Description \\
\hline & Heat shock protein 70 & Maintains internal cell stability like folding-unfolding of proteins \\
& Heat shock protein 90 & Cellular immunity, signal transduction \\
\cline { 2 - 3 } & NB-LRR & PAMPs perception \\
& Hypersensitive induced response protein & Hypersensitive response \\
Post-Harvest Aflatoxin & S-locus glycoprotein & Induction of defense \\
Contamination (PHAC) & Cytochrome P450 & Degradation of toxins \\
& Alcohol dehydrogenase-1F & Detoxification \\
& SAM dependent isoflavone 7-O-methyltransferase & Biosynthesis of phytoalexins \\
\cline { 2 - 3 } & Seed linoleate & Lipid metabolism \\
& Resveratrol synthase & Biosynthesis stilbene type-phytoalexins \\
& ABA responsive genes & Regulates stress responsive genes \\
\hline
\end{tabular}




\section{Pathways Impacting Host-Pathogen Interaction and Toxin Production}

The genome of A. flavus translates 12,000 functional genes and comprises duplication of some lineage-specific genes which give rise to the larger genome i.e., $37 \mathrm{Mb}$ [110]. The complex genome of A. flavus is anticipated to contain $\sim 56$ secondary metabolite gene clusters [111,112]. Among them, the aflatoxin cluster consists of aflatoxin biosynthetic genes as well as pathway-specific regulatory genes, which include 25 genes that span approximately $70 \mathrm{~Kb}$ of DNA [61]. Further, the aflatoxin gene cluster is positioned adjacent to the telomeric region of the third chromosome and is surrounded by four sugar-utilization genes at the distal end [113].

In A. flavus, the production of secondary metabolites is a highly coordinated molecular process involving a dynamic network of transcription factors that orchestrate the coordinated expression of the target biosynthetic genes of the pathogen and suppression of the host immune responses. The aflatoxin biosynthesis pathway-specific regulatory gene aflR encodes a DNA-binding zinc-cluster protein that binds to the promoter region of the aflatoxin pathway genes to trigger their expression [114]. Therefore, overexpression of aflR increases the transcript abundance of aflatoxin pathway genes [115]. Aflatoxin production is also regulated by a pathway-specific regulatory gene aflS, located divergently next to aflR, separated by a small intergenic region and having an independent promoter. Unlike AflR, the role of $A f l S$ is still not well defined because the deletion of aflS does not influence expression of aflatoxin biosynthetic genes. However, surprisingly, the deletion of gene aflS can abolish aflatoxin production in A. flavus [116]. Therefore, it is presumed that AflS can plausibly play a crucial role in aflatoxin biosynthesis through transcriptional regulation of expression of AflR [117], because a synergistic relationship has been observed between AflR and AflS in A. parasiticus [118]. More recently, a study revealed that $A f l S$ is essential for appropriate transportation of $A f l R$ to or from the nucleus and that it assists in AflR localization [119]. Further, DNA methylation plays an important role in mycelial development and secondary metabolism of $A$. flavus. The knock-out of DmtA (a putative cytosine methyltransferase) in A. flavus could result in reduced conidiation and sclerotial production, and attenuate strain virulence due to suppression of aflC, aflK, aflO, aflS and aflR [120]. Recently, a polyamine biosynthetic gene, spermidine synthase (spds), has been characterized as a key gene required by Aspergillus toxigenic strain controlling fungus seed colonization, aflatoxin production and pathogenesis [102].

Despite years of research, geneticists and molecular biologists have yet to find a stable and effective genetic solution to aflatoxin contamination. To date, breeders have identified groundnut germplasm resistant to pre-harvest and post-harvest aflatoxin contamination. Groundnut resistance to Aspergillus spp. involves the production of resveratrol (a natural phytoalexin) by developing seed. Resistant varieties with increased production of resveratrol upon infection exhibit enhanced resistance to in vitro seed colonization [31]. The host defense mechanism involves oxidative homeostasis in response to reactive oxygen species (ROS) formed upon Aspergillus infection. This is achieved by the expression of a wide range of genes involved in ROS detoxification, such as resveratrol synthase, phenylalanine ammonia lyase, chalcone synthase, catalases, superoxide dismutase, glutathione-S-transferase, senescence-associated protein, etc, [31]. Expression of these genes is important to block Aspergillus growth and aflatoxin production [57]. These resistance-conferring genes are involved in producing compounds such as phenylpropanoids, coumarins, stilbenes, cinnamic acid, flavonoids, and ascorbate, etc., which are the primary constituents of the groundnut seed coat $[30,121]$. Furthermore, transcription factors such as WRKY, ERF and NAC are important transcriptional regulators of antioxidant- and pathogenesis-related genes [31,32]. These genes also play an important role in the biosynthesis of volatile compounds such as jasmonate and salicylate [32], and control innate immunity [122]. The genes encoding $\beta$-1,3-glucanases, chitinases, pathogenesis-related proteins and ribosome inactivating proteins (RIPs) are key controllers of A. flavus resistance [57]. It is anticipated that future research will be more focused on dissecting this trait to allow researchers to develop aflatoxin-free groundnuts. 


\section{Integrated Approach for Discovering Genomic Regions and Candidate Genes}

Resistance to A. flavus infection and aflatoxin production is one of the most complex traits influenced by several non-genetic factors such as water stress, population diversity and density of microorganisms in the soil. Nevertheless, extensive phenotyping of large scale germplasm during multiple seasons has identified several lines with minimum infection and aflatoxin production (Table 1). These resistant genotypes are currently being deployed for breeding aflatoxin-resistant lines and to develop different types of genetic populations such as association mapping panels, bi-parental and multi-parent populations [18]. Efforts are also on to deploy transcriptomics, proteomics and metabolomics approaches for a better understanding of the genes, pathways and networks involved in controlling all the three resistance mechanisms, namely IVSC, PAC and AP (see Section 5 and Table 2). ICRISAT, together with its partners, is working on such an integrated approach wherein a MAGIC population and bi-parental populations are planned to be used for genetic mapping and QTL discovery while a mini core collection will be used for association analysis to discover marker-trait associations (MTAs). These studies are likely to facilitate the identification of genomic regions controlling aflatoxin resistance. At the same time, a transcriptomic approach has been deployed to study the functional genomics of resistance mechanisms IVSC, PAC and AP by conducting separate RNAseq experiments. These integrated approaches comprising of genetics, structural genomics and functional genomics together with next-generation sequencing and comprehensive analysis will provide precise information on candidate genes to facilitate the development and validation of genetic markers for use in molecular breeding.

\section{Moving Towards Genomics-Assisted and Transgenic-Based Genetic Improvement to Confer Aflatoxin Resistance}

Developing groundnut cultivars with pre-harvest aflatoxin contamination has been one of the most challenging goals of breeding programs across the globe [123]. Conventional breeding efforts have met with very limited success in breeding aflatoxin-resistant varieties. Majority of the popularly grown varieties across the globe are susceptible to Aspergillus infection and aflatoxin contamination. Given the genetic complexity of this trait, GAB has the potential to enable swifter development of improved varieties with resistance to Aspergillus infection and aflatoxin contamination. However, discovering linked and validated markers is a pre-requisite for deploying GAB. Additionally, a low-density SNP panel (10-50 SNPs) can be developed to perform early generation selection to identify the best lines with resistance to Aspergillus infection and aflatoxin contamination. Limited efforts have been made so far in identifying genomic regions for PAC resistance [88,124], and, therefore, diagnostic markers are not available for use in deploying GAB. Nevertheless, several genetic mapping and association mapping studies on diverse genetic populations are underway and in coming years, multi-parent populations and cost-effective sequencing technologies together with precise phenotyping will facilitate high resolution mapping for aflatoxin resistance to develop a panel of diagnostic markers.

Several studies have reported the use of RNAi to suppress $A$. flavus growth and aflatoxin production in groundnut. For example, an hpRNA construct was successfully deployed in suppressing the expression of five genes (aflR, aflatoxin gene cluster transcriptional activator; aflS, aflatoxin gene cluster transcriptional co-activator; aflC, aflatoxin polyketide synthase; aflep, a putative aflatoxin efflux pump; and pes1, a NRPS responsible for tolerance to oxidative stress) involved either directly or indirectly in aflatoxin biosynthesis [33]. The transgenic groundnut lines showed up to $100 \%$ reduction in $\mathrm{AFB}_{1}$ and $\mathrm{AFB}_{2}$ compared to the control. Another study achieved high level of aflatoxin resistance by overexpressing antifungal defensins genes (MsDef1 and MtDef4.2) through host-induced gene silencing (HIGS) of aflM and aflP genes from the aflatoxin biosynthetic pathway [34]. Aflatoxin $\mathrm{B}_{1}$ levels fell from an average of $2000 \mathrm{ppb}$ in controls to less than $20 \mathrm{ppb}$ (the maximum level allowed by the US FDA) in the RNAi lines as determined by highly sensitive HPLC detection methods. A strong positive correlation was observed between reduction in aflatoxin levels and aflatoxin biosynthetic gene expression using qRT-PCR. These transgenic events will be subjected to further trait verification and 
testing to identify the most promising events with high level of resistance to Aspergillus infection and aflatoxin contamination.

\section{A Mix of Genetic Resistance, Effective Post-Harvest Management Practices and Safe Storage}

Aspergillus infection in groundnuts is usually influenced by the aggressiveness of the fungus, genotype susceptibility, as well as soil moisture and temperature parameters [125]. Moisture stress, especially terminal drought, predisposes groundnut to A. flavus infection and aflatoxin contamination [50,51]. Hence aflatoxin control and prevention strategies mainly include blocking the infection process of $A$. flavus by host-plant resistance/tolerance, biological control, managing environmental factors, pre-harvest crop management and finally post-harvest crop management such as drying and storage technologies $[126,127]$. Under the present scenario, genetic resistance alone cannot eliminate the problem of aflatoxin contamination unless it is used in combination with other pre- and post-harvest management practices [128].

Pre-harvest management includes following in situ (in field) water management techniques which enable the crop to avoid moisture stress at critical stages. Research on the efficacy of water management techniques such as tied ridges and mulching in Zambia have proved that they were effective in significantly reducing pre-harvest aflatoxin contamination in groundnuts [129]. Other cultural practices such as the application of gypsum, a calcium amendment, proved effective in reducing aflatoxin contamination $[44,130]$. Application of manure has also been shown to reduce aflatoxin contamination $[44,131]$. Further research has confirmed that biocontrol using non-aflatoxigenic A. flavus and A. parasiticus strains significantly reduce aflatoxin contamination in groundnuts and maize $[132,133]$.

In the case of groundnut, post-harvest handling of pods from harvest to storage is critical in managing aflatoxin build-up. High pod/seed moisture increases post-harvest molding and aflatoxin contamination. Hence proper drying of pods after harvest to $7 \%$ moisture levels is ideal to prevent the growth of fungi, including aflatoxigenic strains [134]. Earlier research confirmed that inverted windrowing after harvest avoid soil contact of pods, exposes pods to sunlight and reduces groundnut aflatoxin contamination [135]. Research on post-harvest handling showed that dried pods have lower levels of aflatoxins than pods that were not dried. The windrowing, immediate stripping and mat drying of pods are cost effective in controlling damage/molding and subsequent aflatoxin contamination [136]. Storage is another important aspect that care needs to be taken in, in the case of groundnut. Current farmer practice is to use jute and woven polypropylene bags to store groundnut [137]. Storing pods in jute bags provides conditions conducive to mold growth, especially with A. flavus. Jute bags are highly porous and can easily absorb moisture, and therefore foster the rapid growth and multiplication of these aflatoxigenic molds. Alternatively, hermetic storage offers a new alternative to traditional storage of grains and pods, and is a sustainable practice. Hermetic storage works on the principle of creating airtight conditions in which oxygen levels are lowered for insect, fungal and seed respiration. In a recent study conducted at ICRISAT, Purdue Improved Crop Storage (PICS) bags that rely on the principle of hermetic storage were used to safeguard groundnuts against $A$. flavus infestation, and subsequently lowered aflatoxin contamination levels in storage [138].

\section{Challenges and Opportunities}

The age-old problem of aflatoxin contamination has yet to find a sustainable and stable solution. Given its adverse impact on health, the west has set up very stringent criteria for import that prohibits many countries in Africa and Asia from selling their produce to these countries. It is also important to note that the population in the Asian and African countries has shown great tolerance to aflatoxin. Some studies have shown aflatoxin contamination in abundance in the entire food chain, with deleterious effects on the health of consumers. Since A. flavus infection causes no yield loss to the producer and no immediate health impact on consumers, farmers in Asia and Africa have not shown great keenness in 
adopting modern pre-harvest and post-harvest management practices in the processing, packaging, transportation and storage stages. Many farmers are not even aware of the adverse health impact.

Given that health and commerce are equally important, it is essential to minimize aflatoxin contamination in the entire food chain. This would entail deploying more precise phenotyping and diverse genetic populations together with different "omics" approaches to identify genomic regions and candidate genes for accelerated breeding through GAB. Genetic resistance will provide the much needed defense from infection in the field and post-harvest management will ensure less aflatoxin in the produce. A combination of recent advancements in modern genetics, genomics, phenomics resources, tools and technologies along with pre-post-harvest management practices could potentially provide a stable and long term solution for this complex problem.

Funding: This research was supported by the MARS-Wrigley, USA and CGIAR-Natural Science Foundation of China (NSFC), China. The work reported in this article was undertaken as a part of the CGIAR Research Program on Grain Legumes and Dryland Cereals (GLDC). ICRISAT is a member of the CGIAR.

Acknowledgments: RK was supported by Science and Engineering Research Board (SERB), Department of Science and Technology (DST) and SSG acknowledges DST, Govt. of India as he was supported by DST-INSPIRE fellowship for his doctoral studies. The fellowship of PS was supported by Council of Scientific \& Industrial Research (CSIR), Govt. of India.

Conflicts of Interest: The authors declare no conflict of interest.

\section{References}

1. Kurtzman, C.P.; Smiley, M.J.; Robnett, C.J.; Wicklow, D.T. DNA relatedness among wild and domesticated species in the Aspergillus flavus group. Mycologia 1986, 78, 955-959. [CrossRef]

2. Payne, G.A. Aflatoxin in maize. Crit. Rev. Plant Sci. 1992, 10, 423-440. [CrossRef]

3. Goto, T.; Wicklow, D.T.; Ito, Y. Aflatoxin and cyclopiazonic acid production by a sclerotium-producing Aspergillus tamarii strain. Appl. Environ. Microbiol. 1996, 62, 4036-4038. [PubMed]

4. Severns, D.E.; Clements, M.J.; Lambert, R.J.; White, D.G. Comparison of Aspergillus ear rot and aflatoxin contamination in grain of high-oil and normal oil corn hybrids. J. Food Prot. 2003, 66, 637-643. [CrossRef] [PubMed]

5. Amaike, S.; Keller, N.P. Aspergillus flavus. Annu. Rev. Phytopathol. 2011, 49, 107-133. [CrossRef] [PubMed]

6. Kensler, T.W.; Roebuck, B.D.; Wogan, G.N.; Groopman, J.D. Aflatoxin: A 50-year odyssey of mechanistic and translational toxicology. Toxicol. Sci. 2011, 120, S28-S48. [CrossRef] [PubMed]

7. Seo, J.H.; Min, W.K.; Kweon, D.H.; Park, K.; Park, Y.C. Characterization of monoclonal antibody against aflatoxin $\mathrm{B}(1)$ produced in hybridoma $2 \mathrm{C} 12$ and its single-chain variable fragment expressed in recombinant Escherichia coli. Food Chem. 2011, 126, 1316-1323.

8. Awasthi, V.; Bahman, S.; Thakur, L.K.; Singh, S.K.; Dua, A.; Ganguly, S. Contaminants in milk and impact of heating: An assessment study. Indian J. Public Health. 2012, 56, 95. [PubMed]

9. Hameed, H.G. Extrusion and Chemical Treatments for Destruction of Aflatoxin in Naturally-Contaminated Corn. Ph.D. Thesis, University of Arizona, Tucson, AZ, USA, 1993.

10. Saalia, F.K.; Phillips, R.D. Reduction of aflatoxins in peanut meal by extrusion cooking in the presence of nucleophiles. LWT Food Sci. Technol. 2011, 44, 1511-1516. [CrossRef]

11. Torres, P.; Guzmán-Ortiz, M.; Ramírez-Wong, B. Revising the role of $\mathrm{pH}$ and thermal treatments in aflatoxin content reduction during the tortilla and deep frying processes. J. Agric. Food Chem. 2001, 6, 2825-2829. [CrossRef]

12. Waliyar, F.; Ba, A.; Hassan, H.; Bonkoubgou, S.; Bose, J.P. Sources of resistance to aspergillus flavus and aflatoxin contamination in groundnut genotypes in West Africa. Plant Dis. 1992, 78, 704-708. [CrossRef]

13. Thakur, R.P.; Rao, V.P.; Reddy, S.V.; Ferguson, M. Evaluation of wild Arachis germplasm accessions for in vitro seed colonization and aflatoxin production by Aspergillus flavus. Int. Arachis Newslett. 2000, 20, 44-46.

14. Olwari, F.; Bisikwa, J.; Kaaya, A.N.; Okello, D.K. Tolerance levels of peanut varieties against Aspergillus flavus infection. J. Plant Pathol. Microb. 2013, 4, 195. 
15. Korani, W.A.; Chu, Y.; Holbrook, C.; Clevenger, J.; Ozias-Akins, P. Genotypic regulation of aflatoxin accumulation but not aspergillus fungal growth upon post-harvest infection of peanut (Arachis hypogaea L.) Seeds. Toxins 2017, 9, 218. [CrossRef] [PubMed]

16. Dieme, R.M.A.; Faye, I.; Zoclanclounon, Y.A.B.; Fonceka, D.; Ndoye, O.; Diedhiou, P.M. Identification of sources of resistance for Peanut Aspergillus flavus colonization and Aflatoxin contamination. Int. J. Agron. 2018, 2018, 5468602. [CrossRef]

17. Pandey, M.K.; Monyo, E.; Ozias-Akins, P.; Liang, X.; Guimarães, P.; Nigam, S.N.; Upadhyaya, H.D.; Janila, P.; Zhang, X.; Guo, B.; et al. Advances in Arachis genomics for peanut improvement. Biotechnol. Adv. 2012, 30, 639-651. [CrossRef]

18. Pandey, M.K.; Roorkiwal, M.; Singh, V.K.; Ramalingam, A.; Kudapa, H.; Thudi, M.; Chitikineni, A.; Rathore, A.; Varshney, R.K. Emerging genomic tools for legume breeding: Current status and future prospects. Front. Plant Sci. 2016, 7, 455. [CrossRef]

19. Varshney, R.K.; Pandey, M.K.; Bohra, A.; Singh, V.K.; Thudi, M.; Saxena, R.K. Toward the sequence-based breeding in legumes in the post-genome sequencing era. Theor. Appl. Genet. 2019, 132, 797-816. [CrossRef] [PubMed]

20. Chen, X.; Li, H.; Pandey, M.K.; Yang, Q.; Wang, X.; Garg, V.; Li, H.; Chi, X.; Doddamani, D.; Hong, Y.; et al. Draft genome of the peanut A-genome progenitor (Arachis duranensis) provides insights into geocarpy, oil biosynthesis, and allergens. Proc. Natl. Acad. Sci. USA 2016, 113, 6785-6790. [CrossRef]

21. Bertioli, D.J.; Cannon, S.B.; Froenicke, L.; Huang, G.; Farmer, A.D.; Cannon, E.K.; Liu, X.; Gao, D.; Clevenger, J.; Dash, S.; et al. The genome sequences of Arachis duranensis and Arachis ipaensis, the diploid ancestors of cultivated peanut. Nat. Genet. 2016, 48, 438-446. [CrossRef]

22. Lu, Q.; Li, H.; Hong, Y.; Zhang, G.; Wen, S.; Li, X.; Zhou, G.; Li, S.; Liu, H.; Liu, H.; et al. Genome sequencing and analysis of the peanut B-genome progenitor (Arachis ipaensis). Front. Plant Sci. 2018, 9, 604. [CrossRef] [PubMed]

23. Yin, D.; Ji, C.; Ma, X.; Li, H.; Zhang, W.; Li, S.; Liu, F.; Zhao, K.; Li, F.; Li, K.; et al. Genome of an allotetraploid wild peanut Arachis monticola: A de novo assembly. GigaScience 2018, 7, giy066. [CrossRef] [PubMed]

24. Bertioli, D.J.; Jenkins, J.; Clevenger, J.; Gao, D.; Dudchenko, O.; Seijo, G.; Leal-Bertioli, S.; Ren, L.; Farmer, A.; Pandey, M.K.; et al. The genome sequence of peanut (Arachis hypogaea), a segmental allotetraploid. Nat. Genet. 2019. [CrossRef] [PubMed]

25. Chen, X.; Lu, Q.; Liu, H.; Zhang, J.; Hong, Y.; Lan, H.; Li, H.; Wang, J.; Liu, H.; Li, S.; et al. Sequencing of cultivated peanut, Arachis hypogaea, yields insights into genome evolution and oil improvement. Mol. Plant. 2019. [CrossRef] [PubMed]

26. Zhuang, W.; Chen, H.; Yang, M.; Wang, J.; Pandey, M.K.; Zhang, C.; Chang, W.-C.; Zhang, L.; Zhang, X.; Tang, R.; et al. The Arachis hypogaea genome elucidates legume karyotypes, polyploid evolution and crop domestication. Nat. Genet. 2019. [CrossRef]

27. Clevenger, J.; Chu, Y.; Arrais, G.L.; Maia, T.; Bertioli, D.; Leal-Bertioli, S.; Timper, P.; Holbrook, C.C.; Ozias-Akins, P. Gene expression profiling describes the genetic regulation of Meloidogyne arenaria resistance in Arachis hypogaea and reveals a candidate gene for resistance. Sci. Rep. 2017, 7, 1317. [CrossRef] [PubMed]

28. Sinha, P.; Bajaj, P.; Pazhamala, P.T.; Nayak, S.N.; Pandey, M.K.; Chitikineni, A.; Huai, D.; Khan, A.W.; Desai, A.; Guo, B.; et al. VI NGGIBCI Conference on Crop Genomics: Present E Future; ICRISAT: Hyderabad, India, 7-8 December 2017.

29. Pandey, M.K.; Agarwal, G.; Kale, S.M.; Clevenger, J.; Nayak, S.N.; Sriswathi, M.; Chitikineni, A.; Chavarro, C.; Chen, X.; Upadhyaya, H.D.; et al. Development and evaluation of a high density genotyping 'Axiom_Arachis' array with 58 K SNPs for accelerating genetics and breeding in groundnut. Sci. Rep. 2017, 7, 40577. [CrossRef] [PubMed]

30. Wang, H.; Lei, Y.; Wan, L.; Yan, L.; Lv, J.; Dai, X.; Ren, X.; Guo, W.; Jiang, H.; Liao, B. Comparative transcript profiling of resistant and susceptible peanut post-harvest seeds in response to aflatoxin production by Aspergillus flavus. BMC Plant Biol. 2016, 1, 54. [CrossRef] [PubMed]

31. Nayak, S.N.; Agarwal, G.; Pandey, M.K.; Sudini, H.K.; Jayale, A.S.; Purohit, S.; Desai, A.; Wan, L.; Guo, B.; Liao, B.; et al. Aspergillus favus infection triggered immune responses and host-pathogen cross-talks in groundnut during in-vitro seed colonization. Sci. Rep. 2017, 7, 9659. [CrossRef]

32. Korani, W.; Chu, Y.; Holbrook, C.C.; Ozias-Akins, P. Insight into genes regulating postharvest aflatoxin contamination of tetraploid peanut from transcriptional profiling. Genetics 2018, 209, 143-156. [CrossRef] 
33. Arias, R.S.; Dang, P.M.; Sobolev, V.S. RNAi-mediated control of aflatoxins in peanut: Method to analyse mycotoxin production and transgene expression in the peanut/Aspergillus pathosystem. J. Vis. Exp. 2015, 106, e53398. [CrossRef]

34. Sharma, K.K.; Pothana, A.; Prasad, K.; Shah, D.; Kaur, J.; Bhatnagar, D.; Chen, Z.Y.; Raruang, Y.; Cary, J.W.; Rajasekaran, K.; et al. Peanuts that keep aflatoxin at bay: A threshold that matters. Plant Biotechnol. J. 2018, 16, 1024-1033. [CrossRef] [PubMed]

35. Lakkireddy, K.; Kondapalli, K.; Rao, K.R.S. Aflatoxins in food and feed: The science of safe food. J. Food Sci. Technol. 2014, 2, 6-11.

36. Ehrlich, K.C. Non-aflatoxigenic Aspergillus flavus to prevent aflatoxin contamination in crops: Advantages and limitations. Front. Microbiol. 2014, 5, 50. [CrossRef] [PubMed]

37. Horn, B.W.; Moore, G.G.; Carbone, I. Sexual reproduction in Aspergillus flavus. Mycologia 2009, 101, $423-429$. [CrossRef]

38. Horn, B.W.; Greene, R.L.; Dorner, J.W. Effect of corn and peanut cultivation on soil populations of Aspergillus flavus and Aspergillus parasiticus in southwestern Georgia. Appl. Environ. Microbiol. 1995, 61, 2472-2475.

39. Horn, B.W.; Dorner, J.W. Soil population of Aspergillus species from section Flavi along a transect through peanut-growing regions of the United States. Mycologia 1998, 90, 767-776. [CrossRef]

40. Molyneux, R.J.; Mahoney, N.; Kim, J.H.; Campbell, B.C. Mycotoxins in edible tree nuts. Int. J. Food Microbiol. 2007, 119, 72-78. [CrossRef]

41. Cotty, P.J. Virulence and cultural characteristics of two Aspergillus flavus strains pathogenic on cotton. Phytopathologia 1989, 79, 808-814. [CrossRef]

42. Miller, J.D. Mycotoxins in small grains and maize: Old problems, new challenges. Food Addit. Contam. 2008, 25, 219-230. [CrossRef]

43. Upadhyaya, H.D.; Nigam, S.N.; Thakur, R.P. Genetic enhancement for resistance to aflatoxin contamination in groundnut. In Summary proceedings of the Seventh ICRISAT Regional Groundnut Meeting for Western and Central Africa, Cotonu, Benin, 6-8 December 2000; International Crops Research Institute for the Semi-Arid Tropics: Patancheru, India, 2002; pp. 29-36.

44. Waliyar, F.; Ntare, B.R.; Diallo, A.T.; Kodio, O.; Diarra, B. On-Farm Management of Aflatoxin Contamination of Groundnut in West Africa: A Synthesis Report; International Crops Research Institute for the Semi-Arid Tropics: Patancheru, India, 2007.

45. Wilson, D.M.; Stansell, J.R. Effect of irrigation regimes on aflatoxin contamination of peanut pods. Peanut Sci. 1983, 10, 54-56. [CrossRef]

46. Cole, R.J.; Sanders, T.H.; Hill, R.A.; Blankenship, P.D. Mean geocarposphere temperatures that induce pre-harvest aflatoxin contamination of peanuts under drought stress. Mycopathologia 1985, 91, 41-46. [CrossRef] [PubMed]

47. Girdthai, T.; Jogloy, S.; Vorasoot, N.; Akkasaeng, C.; Wongkaew, S.; Holbrook, C.C.; Patanothai, A. Associations between physiological traits for drought tolerance and aflatoxin contamination in peanut genotypes under terminal drought. Plant Breed. 2010, 129, 693-699. [CrossRef]

48. Sudhakar, P.; Latha, P.; Babitha, M.; Reddy, P.V.; Naidu, P.H. Relationship of drought tolerance traits with aflatoxin contamination in groundnut. Indian J. Plant Physiol. 2007, 3, 261.

49. Dorner, J.W.; Cole, R.J.; Sanders, T.H.; Blankenship, P.D. Interrelationship of kernel water activity, soil temperature, maturity, and phytoalexin production in preharvest aflatoxin contamination of drought-stressed peanuts. Mycopathologia 1989, 105, 117-128. [CrossRef]

50. Waliyar, F.; Traore, D.; Fatondji, D.; Ntare, B.R. Effect of irrigation interval, planting date, and cultivar on Aspergillus flavus and aflatoxin contamination of peanut in a sandy soil of Niger. Peanut Sci. 2003, 30, 79-84. [CrossRef]

51. Hamidou, F.; Rathore, A.; Waliyar, F.; Vadez, V. Although drought intensity increases aflatoxin contamination, drought tolerance does not lead to less aflatoxin contamination. Field Crops Res. 2014, 156, 103-110. [CrossRef]

52. Bayram, O.; Krappmann, S.; Ni, M.; Bok, J.W.; Helmstaedt, K.; Valerius, O.; Braus, G.H. VelB/VeA/LaeA complex coordinates light signal with fungal development and secondary metabolism. Science 2008, 320, 1504-1506. [CrossRef]

53. Buchanan, R.L.; Stahl, H.G. Ability of various carbon sources to induce and support aflatoxin synthesis by Aspergillus parasiticus. J. Food Saf. 1984, 6, 271-279. [CrossRef] 
54. Shih, C.N.; Marth, E.H. Aflatoxin formation, lipid synthesis, and glucose metabolism by Aspergillus parasiticus during incubation with and without agitation. Biochem. Biophys. Acta 1974, 338, 286-296. [CrossRef]

55. Clevstrom, G.; Ljunggren, H.; Tegelstrom, S.; Tideman, K. Production of aflatoxin by an Aspergillus flavus isolate cultured under a limited oxygen supply. Appl. Environ. Microbiol. 1983, 46, 400-405.

56. Watanabe, C.M.H.; Wilson, D.; Linz, J.E.; Townsend, C.A. Demonstration of the catalytic roles and evidence for the physical association of type I fatty acid synthases and a polyketide synthase in the biosynthesis of aflatoxin B1. Chem. Biol. 1996, 3, 463-469. [CrossRef]

57. Fountain, J.C.; Khera, P.; Yang, L.; Nayak, S.N.; Scully, B.T.; Lee, R.D.; Chen, Z.Y.; Kemerait, R.C.; Varshney, R.K.; Guo, B. Resistance to Aspergillus flavus in maize and peanut: Molecular biology, breeding, environmental stress, and future perspectives. Crop J. 2015, 3, 229-237. [CrossRef]

58. Brown, D.W.; Yu, J.H.; Kelkar, H.S.; Fernandes, M.; Nesbitt, T.C.; Keller, N.P.; Adams, T.H.; Leonard, T.J. Twenty-five co-regulated transcripts define a sterigmatocystin gene cluster in Aspergillus nidulans. Proc. Natl. Acad. Sci. USA 1996, 93, 1418-1422. [CrossRef] [PubMed]

59. Liu, B.H.; Chu, F.S. Regulation of aflR and its product, AflR, associated with aflatoxin biosynthesis. Appl. Environ. Microbiol. 1998, 64, 3718-3723. [PubMed]

60. Bhatnagar, D.; Ehrlich, K.C.; Cleveland, T.E. Molecular genetic analysis and regulation of aflatoxin biosynthesis. Appl. Microbiol. Biotechnol. 2003, 61, 83-93. [CrossRef] [PubMed]

61. Yu, J.; Bhatnagar, D.; Cleveland, T.E. Completed sequence of aflatoxin pathway gene cluster in Aspergillus parasiticus. FEBS Lett. 2004, 564, 126-130. [CrossRef]

62. Georgianna, D.R.; Payne, G.A. Genetic regulation of aflatoxin biosynthesis: From gene to genome. Fungal Genet. Biol. 2009, 46, 113-125. [CrossRef]

63. Calvo, A.M. The VeA regulatory system and its role in morphological and chemical development in fungi. Fungal Genet. Biol. 2008, 45, 1053-1061. [CrossRef] [PubMed]

64. Strosnider, H.; Azziz-Baumgartner, E.; Banziger, M.; Bhat, R.V.; Breiman, R.; Brune, M.N.; DeCock, K.; Dilley, A.; Groopman, J.; Hell, K.; et al. Workgroup report: Public health strategies for reducing aflatoxin exposure in developing countries. Environ. Health Perspect. 2006, 114, 1898-1903. [CrossRef]

65. Krishnamachari, K.A.; Bhat, R.V.; Nagarajan, V.; Tilak, T.B. Hepatitis due to aflatoxicosis. An outbreak in Western India. Lancet 1975, 1, 1061-1063. [CrossRef]

66. Liu, Y.; Wu, F. Global burden of aflatoxin-induced hepatocellular carcinoma: A risk assessment. Environ. Health Perspect. 2010, 118, 818-824. [CrossRef] [PubMed]

67. Valery, P.C.; Laversanne, M.; Clark, P.J.; Petrick, J.L.; McGlynn, K.A.; Bray, F. Projections of primary liver cancer to 2030 in 30 countries worldwide. Hepatology 2018, 67, 600-611. [CrossRef] [PubMed]

68. Gopal, T.; Zaki, S.; Narayanaswami, M.; Premlata, S. Aflatoxicosis in fowls. Indian Vet. J. 1969, 46, 348-349.

69. Blount, W.P. Turkey "X" disease. Turkeys 1961, 9, 52-67.

70. Wannop, C.C. The histopathology of turkey "X" disease in Great Britain. Avian Dis. 1961, 5, 371-381. [CrossRef]

71. Kelly, J.D.; Eaton, D.L.; Guengerich, F.P.; Coulombe, R.J. Aflatoxin B sub (1) activation in human lung. Toxicol. Appl. Pharmacol. 1997, 144, 88-95. [CrossRef]

72. Wang, J.S.; Huang, T.; Su, J.; Liang, F.; Wei, Z.; Liang, Y.; Luo, H.; Kuang, S.Y.; Qian, G.S.; Sun, G.; et al. Hepatocellular carcinoma and aflatoxin exposure in Zhuqing village, Fusui county, People's Republic of China. Cancer Epidemiol. Prev. Biomark. 2001, 10, 143-146.

73. Tajkarimi, M.; Shojaee, M.H.; Yazdanpanah, H.; Ibrahim, S.A. Aflatoxin in agricultural commodities and herbal medicine. In Aflatoxins-Biochemistry and Molecular Biology; IntechOpen: London, UK, 2011. [CrossRef]

74. Gbashi, S.; Madala, N.E.; Adekoya, I.; Adebo, O.; De Saeger, S.; De Boevre, M.; Njobeh, P.B. The socio-economic impact of mycotoxin contamination in Africa. In Fungi and Mycotoxins-Their Occurrence, Impact on Health and the Economy as well as Pre- and Postharvest Management Strategies; InTechOpen: London, UK, 2018. [CrossRef]

75. Coulibaly, O.; Hell, K.; Bandyopadhyay, R.; Hounkponou, S.; Leslie, J.F. Economic impact of aflatoxin contamination in Sub-Saharan Africa. In Mycotoxins Detection Methods, Management, Public Health and Agricultural Trade, 1st ed.; Leslie, J., Bandyopadhyay, R., Visconti, A., Eds.; CABI Publishing: Cambridge, UK, 2008; pp. 67-76.

76. Hendrickse, R.G.; Coulter, J.B.; Lamplugh, S.M.; Macfarlane, S.B.; Williams, T.E.; Omer, M.I.; Suliman, G.I. Aflatoxins and kwashiorkor: A study in Sudanese children. Br. Med. J. (Clin. Res. Ed.) 1982, 285, 843-846. [CrossRef] 
77. Ramjee, G.; Berjak, P.; Adhikari, M.; Dutton, M.F. Aflatoxins and kwashiorkor in Durban, South Africa. Ann. Trop. Paediatr. 1992, 12, 241-247. [CrossRef]

78. Lamplugh, S.M.; Hendrickse, R.G. Aflatoxins in the livers of children with kwashiorkor. Ann. Trop. Paediatr. 1982, 2, 101-104. [CrossRef] [PubMed]

79. Wagacha, J.M.; Muthomi, J.W. Mycotoxin problem in Africa: Current status, implications to food safety and health and possible management strategies. Int. J. Food Microbiol. 2008, 124, 1-12. [CrossRef] [PubMed]

80. Gebrehiwet, Y.; Kirsten, J.; Qangweni, W. Quantifying the trade effect of sanitary and phytosanitary regulations of Organization for Economic Cooperation and Development (OECD) countries on South African food exports. Agrekon 2007, 46, 1-17. [CrossRef]

81. Hall, A.J.; Wild, C.P. Epidemiology of aflatoxin-related disease. In The Toxicology of Aflatoxins: Human Health, Veterinary, and Agricultural Significance; Eaton, D.L., Groopman, J.D., Eds.; Academic Press: London, UK, 1993; pp. 233-258.

82. Paterson, R.R.; Lima, N. Toxicology of mycotoxins. EXS 2010, 100, 31-63.

83. Williams, J.H.; Phillips, T.D.; Jolly, P.E.; Stiles, J.K.; Jolly, C.M.; Aggarwal, D. Human aflatoxicosis in developing countries: A review of toxicology, exposure, potential health consequences, and interventions. Am. J. Clin. Nutr. 2004, 80, 1106-1122. [CrossRef] [PubMed]

84. Awuah, R.T.; Kpodo, K.A. High incidence of Aspergillus flavus and aflatoxins in stored groundnut in Ghana and the use of a microbial assay to assess the inhibitory effects of plant extracts on aflatoxin synthesis. Mycopathologia 1996, 134, 109-114. [CrossRef]

85. Sharma, R.K.; Parisi, S. Toxins and Contaminants in Indian Food Products; Springer International Publishing: New York, NY, USA, 2017; pp. 13-24.

86. Cooper, J.; Dobson, H. The benefits of pesticides to mankind and the environment. Crop Prot. 2007, 23, 1337-1348. [CrossRef]

87. Lawley, T.D.; Walker, A.W. Intestinal colonization resistance. Immunology 2013, 138, 1-11. [CrossRef]

88. Yu, B.; Huai, D.; Huang, L.; Kang, Y.; Ren, X.; Chen, Y.; Zhou, X.; Luo, H.; Liu, N.; Chen, W.; et al. Identification of genomic regions and diagnostic markers for resistance to aflatoxin contamination in peanut (Arachis hypogaea L.). BMC Genet. 2019, 20, 32. [CrossRef]

89. Holbrook, C.C.; Wilson, D.M.; Matheron, M.E.; Hunter, J.E.; Knauft, D.A.; Gorbet, D.W. Aspergillus colonization and aflatoxin contamination in peanut genotypes with reduced linoleic acid composition. Plant Dis. 2000, 84 148-150. [CrossRef]

90. ICRISAT (International Crops Research Institute for the Semi-Arid Tropics). Aflatoxin contamination of groundnut: Proceedings of the international workshop, 6-9 October 1987; ICRISAT: Patancheru, India, 1987.

91. ICRISAT Center. Aflatoxin contamination of groundnut: proceedings of the International Workshop. 6-9 October 1987, ICRISAT Center, India; ICRISAT: Patancheru, India, 1989.

92. Mixon, A.C.; Rogers, K.M. Peanut accessions resistant to seed infection by Aspergillus flavus. Agron. J. 1973, 65, 560-562. [CrossRef]

93. Kisyombe, C.T.; Beute, M.K.; Payne, G.A. Field evaluation of peanut genotypes for resistance to infection by Aspergillus parasiticus. Peanut Sci. 1985, 12, 12-17. [CrossRef]

94. Anderson, W.F.; Holbrook, C.C.; Wilson, D.M.; Matheron, M.E. Evaluation of peanut aflatoxin contamination in several potentially resistant peanut genotypes. Peanut Sci. 1995, 22, 29-32. [CrossRef]

95. Mehan, V.K.; McDonald, D. Research on the aflatoxin problem in groundnut at ICRISAT. Plant and Soil. 1979, 79, 255-260. [CrossRef]

96. Jiang, H.F.; Ren, X.P.; Wang, S.Y.; Zhang, X.J.; Huang, J.Q.; Liao, B.S.; Holbrook, C.C.; Upadhyaya, H.D. Development and evaluation of peanut germplasm with resistance to Aspergillus flavus from core collection. Acta Agron. Sin. 2010, 3, 428-434. [CrossRef]

97. Guo, B.; Fedorova, N.D.; Chen, X.; Wan, C.H.; Wang, W.; Nierman, W.C.; Bhatnagar, D.; Yu, J. Gene expression profiling and identification of resistance genes to Aspergillus flavus infection in peanut through EST and microarray strategies. Toxins 2011, 3, 737-753. [CrossRef] [PubMed]

98. Guo, B.; Chen, X.; Dang, P.; Scully, B.T.; Liang, X.; Holbrook, C.C.; Yu, J.; Culbreath, A.K. Peanut gene expression profiling in developing seeds at different reproduction stages during Aspergillus parasiticus infection. BMC Dev. Biol. 2008, 8, 12. [CrossRef] [PubMed] 
99. Wang, Z.; Yan, S.; Liu, C.; Chen, F.; Wang, T. Proteomic analysis reveals an aflatoxin-triggered immune response in cotyledons of Arachis hypogaea infected with Aspergillus flavus. J. Proteome Res. 2012, 11, 2739-2753. [CrossRef] [PubMed]

100. Bedre, R.; Rajasekaran, K.; Mangu, V.R.; Timm, L.E.; Bhatnagar, D.; Baisakh, N. Genome-wide transcriptome analysis of cotton (Gossypium hirsutum L.) identifies candidate gene signatures in response to aflatoxin producing fungus Aspergillus flavus. PLoS ONE 2015, 14, 0138025. [CrossRef]

101. Wang, H.; Lei, Y.; Yan, L.; Cheng, K.; Dai, X.; Wan, L.; Guo, W.; Cheng, L.; Liao, B. Deep sequencing analysis of transcriptomes in Aspergillus flavus in response to resveratrol. BMC Microbiol. 2015, 15, 182. [CrossRef] [PubMed]

102. Majumdar, R.; Lebar, M.; Mack, B.; Minocha, R.; Minocha, S.; Carter-Wientjes, C.; Sickler, C.; Rajasekaran, K.; Cary, J.W. The Aspergillus flavus Spermidine synthase (spds) gene, is required for normal development, aflatoxin production, and pathogenesis during infection of maize kernels. Front. Plant Sci. 2018, 9, 317. [CrossRef] [PubMed]

103. Chen, Z.Y.; Brown, R.L.; Damann, K.E.; Cleveland, T.E. Identification of unique or elevated levels of kernel proteins in aflatoxin-resistant maize genotypes through proteome analysis. Phytopatholgia 2002, 92, 1084-1094. [CrossRef] [PubMed]

104. Brown, R.L.; Chen, Z.Y.; Warburton, M.; Luo, M.; Menkir, A.; Fakhoury, A.; Bhatnagar, D. Discovery and characterization of proteins associated with aflatoxin-resistance: Evaluating their potential as breeding markers. Toxins 2010, 2, 919-933. [CrossRef] [PubMed]

105. Wang, T.; Zhang, E.; Chen, X.; Li, L.; Liang, X. Identification of seed proteins associated with resistance to pre-harvested aflatoxin contamination in peanut (Arachis hypogaea L). BMC Plant Biol. 2010, 10, 267. [CrossRef] [PubMed]

106. Fountain, J.C.; Koh, J.; Yang, L.; Pandey, M.K.; Nayak, S.N.; Bajaj, P.; Zhuang, W.J.; Chen, Z.Y.; Kemerait, R.C.; Lee, R.D.; et al. Proteome analysis of Aspergillus flavus isolate-specific responses to oxidative stress in relationship to aflatoxin production capability. Sci. Rep. 2018, 8, 3430. [CrossRef] [PubMed]

107. Thakare, D.; Zhang, J.; Wing, R.A.; Cotty, P.J.; Schmidt, M.A. Aflatoxin-free transgenic maize using host-induced gene silencing. Sci. Adv. 2017, 3, e1602382. [CrossRef] [PubMed]

108. Clevenger, J.; Marasigan, K.; Liakos, V.; Sobolev, V.; Vellidis, G.; Holbrook, C.; Ozias-Akins, P. RNA sequencing of contaminated seeds reveals the state of the seed permissive for pre-harvest aflatoxin contamination and points to a potential susceptibility factor. Toxins 2016, 8, 317. [CrossRef]

109. Wang, T.; Chen, X.; Li, H.; Liu, H.; Hong, Y.; Yang, Q.; Chi, X.Y.; Yang, Z.; Yu, S.L.; Li, B.L.; et al. Transcriptome identification of the resistance-associated genes (RAGs) to Aspergillus flavus infection in pre-harvested peanut (Arachis hypogaea). Funct. Plant Biol. 2013, 40, 292-303. [CrossRef]

110. Rokas, A.; Payne, G.; Fedorova, N.D.; Baker, S.E.; Machida, M.; Yu, J.; Georgianna, D.R.; Dean, R.A.; Bhatnagar, D.; Cleveland, T.E.; et al. What can comparative genomics tell us about species concepts in the genus Aspergillus? Stud. Mycol. 2007, 59, 11-17. [CrossRef]

111. Georgianna, D.R.; Fedorova, N.D.; Burroughs, J.L.; Dolezal, A.L.; Bok, J.W.; Horowitz-Brown, S.I.; Woloshuk, C.P.; Yu, J.; Keller, N.P.; Payne, G.A. Beyond aflatoxin: Four distinct expression patterns and functional roles associated with Aspergillus flavus secondary metabolism gene clusters. Mol. Plant Pathol. 2010, 11, 213-226. [CrossRef]

112. Marui, J.; Yamane, N.; Ohashi-Kunihiro, S.; Ando, T.; Terabayashi, Y.; Sano, M.; Ohashi, S.; Ohshima, E.; Tachibana, K.; Higa, Y.; et al. Kojic acid biosynthesis in Aspergillus oryzae is regulated by a Zn(II)(2)Cys(6) transcriptional activator and induced by kojic acid at the transcriptional level. J. Biosci. Bioeng. 2011, 112, 40-43. [CrossRef] [PubMed]

113. Yu, J.; Chang, P.K.; Bhatnagar, D.; Cleveland, T.E. Cloning of a sugar utilization gene cluster in Aspergillus parasiticus. Biochem. Biophys. Acta 2000, 1493, 211-214. [CrossRef]

114. Amare, M.G.; Keller, N.P. Molecular mechanisms of Aspergillus flavus secondary metabolism and development. Fungal Genet. Biol. 2014, 66, 11-18. [CrossRef] [PubMed]

115. Flaherty, J.E.; Payne, G.A. Overexpression of aflR leads to upregulation of pathway gene transcription and increased aflatoxin production in Aspergillus flavus. Appl. Environ. Microbiol. 1997, 63, 3995-4000. [PubMed]

116. Meyers, D.M.; Obrian, G.; Du, W.L.; Bhatnagar, D.; Payne, G.A. Characterization of aflJ, a gene required for conversion of pathway intermediates to aflatoxin. Appl. Environ. Microbiol. 1998, 64, 3713-3717. 
117. Chang, P.K. The Aspergillus parasiticus protein AFLJ interacts with the aflatoxin pathway-specific regulator AFLR. Mol. Genet. Genom. 2003, 268, 711-719.

118. Chang, P.K.; Yu, J.; Yu, J.H. aflT a MFS transporter-encoding gene located in the aflatoxin gene cluster, does not have a significant role in aflatoxin secretion. Fungal Genet. Biol. 2004, 41, 911-920. [CrossRef]

119. Ehrlich, K.C.; Mack, B.M.; Wei, Q.; Li, P.; Roze, L.V.; Dazzo, F.; Cary, J.; Bhatnagar, D.; Linz, J. Association with $A f l R$ in endosomes reveals new functions for $A f l J$ in aflatoxin biosynthesis. Toxins 2012, 4, 1582-1600. [CrossRef]

120. Yang, K.; Liang, L.; Ran, F.; Liu, Y.; Li, Z.; Lan, H.; Gao, P.; Zhuang, Z.; Zhang, F.; Nie, X.; et al. The DmtA methyltransferase contributes to Aspergillus flavus conidiation, sclerotial production, aflatoxin biosynthesis and virulence. Sci. Rep. 2016, 6, 23259. [CrossRef]

121. Wan, L.; Li, B.; Lei, Y.; Yan, L.; Huai, D.; Kang, Y.; Jiang, H.; Tan, J.; Liao, B. Transcriptomic profiling reveals pigment regulation during peanut testa development. Plant Physiol. Biochem. 2018, 125, 116-125. [CrossRef]

122. Solano, R.; Gimenez-Ibanez, S. Nuclear jasmonate and salicylate signaling and crosstalk in defense against pathogens. Front. Plant Sci. 2013, 4, 72.

123. Blankenship, P.; Cole, R.; Sanders, T.; Hill, R. Effect of geo carposphere temperature on pre-harvest colonization of drought-stressed peanuts by Aspergillus flavus and subsequent aflatoxin contamination. Mycopathologia 1984, 85, 69-74. [CrossRef] [PubMed]

124. Liang, X.; Zhou, G.; Hong, Y.; Chen, X.; Liu, H.; Li, S. Overview of research progress on peanut (Arachis hypogaea L.) host resistance to aflatoxin contamination and genomics at the Guangdong Academy of Agricultural Sciences. Peanut Sci. 2009, 36, 29-34. [CrossRef]

125. Assis, R.; Barrionuevo, D.L.; Giorda, L.M.; Nores, M.E.; Aldao, M.A. Aflatoxin production in six peanut (Arachis hypogaea L.) genotypes infected with Aspergillus flavus and Aspergillus parasiticus, isolated from peanut production areas of Cordoba, Argentina. J. Agric. Food Chem. 2005, 53, 9274-9280. [CrossRef] [PubMed]

126. Waliyar, F.; Kumar, P.L.; Traoré, A.; Ntare, B.R.; Diarra, B.; Kodio, O. Pre and post-harvest management of aflatoxin contamination in peanuts. In Mycotoxins: Detection Methods, Management, Public Health and Agricultural Trade; Leslie, J.F., Bandyopadhyay, R., Visconti, A., Eds.; CABI: Wallingford, UK, 2008; pp. 209-218.

127. Hell, K.; Mutegi, C. Aflatoxin control and prevention strategies in key crops of Sub-Saharan Africa. Afr. J. Microbiol. Res. 2011, 55, 459-466.

128. Nigam, S.N.; Waliyar, F.; Aruna, R.; Reddy, S.V.; Kumar, P.L.; Craufurd, P.Q.; Diallo, A.T.; Ntare, B.R.; Upadhyaya, H.D. Breeding for resistance to aflatoxin contamination at ICRISAT. Peanut Sci. 2009, 36, 42-49. [CrossRef]

129. Njoroge, S.M.C. A critical review of aflatoxin contamination of peanuts in Malawi and Zambia: The past, present, and future. Plant Dis. 2018, 102, 2394-2406. [CrossRef]

130. Mixon, A.C.; Bell, D.K.; Wilson, D.M. Effect of chemical and biological agents on the incidence of A. flavus and aflatoxin contamination of peanut seed. Phytopatho 1984, 74, 1440-1444. [CrossRef]

131. Chalwe, H.; Mweetwa, A.M.; Lungu, O.I.; Phiri, E.; Njoroge, S.; Brandenburg, R. Reducing pre-harvest aflatoxin content in groundnuts through soil water. RUFORUM Work. Doc. Ser. 2016, 14, 921-926. Available online: http://repository.ruforum.org (accessed on 30 March 2019).

132. Dorner, J.W. Development of biocontrol technology to manage aflatoxin contamination in peanuts. Peanut Sci. 2009, 36, 60-67. [CrossRef]

133. Bandyopadhyay, R.; Cotty, P.J. Biological controls for aflatoxin reduction. In Aflatoxins: Finding Solutions for Improved Food Safety; Grace, D., Unnevehr, L., Eds.; International Food Policy Research Institute: Washington, DC, USA, 2013.

134. Dick, K.M. Pest Management in Stored Groundnuts. Information Bulletin 22; ICRISAT: Patancheru, India, 1987; p. 28.

135. Devi, R.; Hall, A. Strategies for reducing aflatoxin levels in groundnut based foods and feeds in India: A step towards improving health of humans and livestocks; Section C: Scientific Background; ICRISAT: Patancheru, India, 2000; pp. 9-17.

136. Attah, I.A.; Awuah, R.T.; Kpodo, K.A.; Fialor, S.C.; Jolly, C.M. Cost effectiveness of selected post-harvest pod handling techniques against damage, mouldiness and aflatoxin contamination of shelled groundnut in Ghana. J. Food Sci. Technol. 2007, 27, 17-26. 
137. Bulaong, S.S.P.; Dharmaputra, O.S. Fungal population, aflatoxin and free fatty acid contents of peanuts packed in different bag types. Biotropica 2002, 19, 1-25.

138. Sudini, H.; Ranga Rao, G.V.; Gowda, C.L.L.; Chandrika, R.; Margam, V.; Rathore, A.; Murdock, L.L. Purdue Improved Crop Storage (PICS) bags for safe storage of groundnuts. J. Stored Prod. Res. 2015, 64, 133-138. [CrossRef]

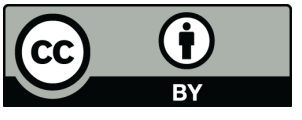

(C) 2019 by the authors. Licensee MDPI, Basel, Switzerland. This article is an open access article distributed under the terms and conditions of the Creative Commons Attribution (CC BY) license (http://creativecommons.org/licenses/by/4.0/). 